\title{
Photovoltaic System Integration Where Feed-In Tariff Applied With Improving Return On Investment
}

\author{
Fadi M. Albatsh ${ }^{\mathrm{a}}$, Bilal M. Eid ${ }^{\mathrm{b}}$, Nasrudin A. Rahim ${ }^{\mathrm{b}}$
}

\begin{abstract}
High photovoltaic (PV) integration in electrical grid is one of the strategic goals for many countries nowadays. That's why many governments introduced incentive policies seeking for PV projects funded by private sector. These kinds of projects have to be a positive net present value (NPV) in order to get sponsorship by non-government sector. This paper investigates the PV solar system financial analysis in Malaysia and Turkey. In developing counties, the governments are looking for more renewable energy (RE) sources installation. Thus, they implemented Feed-in Tariff (FiT) mechanism to accelerate investment in renewable energy technologies. As the efficiency of the PV cell increases and the cost/Wp decreases with time, the expected net present value (NPV), return on investment (ROI) and payback period for the PV system are going to achieve a significant increase. The $F i T$ rate in Malaysia is significantly higher than Turkey and the purchase agreement is longer. These advantages would make Malaysia a better place for PV system investment. Moreover, this paper proposed the PV system to be installed at the roof of building, merged with another suitable business such as; roller skating rink or cafe. This combination makes the PV project making income at day time via solar radiation, while generating income at evening and night time via the other business. The analysis results revealed that, the combination of PV system with roller skating rink or cafe can reduce the payback period and make a wonderful combination between green energy and people.
\end{abstract}

Keywords - photovoltaic, Feed-in Tariff (FiT), Net Present Value (NPV), Return on Investment (ROI), green energy

\section{Introduction}

The increased demand for power that had to be transferred over long distances and continual load growth, make the integration of distribution energy resources (DERs) an effective and fast solution [1-2] .DER features include; reducing the electrical and physical distances between load and generator, improving reactive power to enhance grid voltage profile and power stability, removing bottlenecks from distribution and transmission lines, reducing transmission and distribution losses, making better use of waste heat, postponing the necessity to establish new transmission lines and huge power generation plants, and

${ }^{\mathrm{a}}$ Fadi M. Albatsh

Electrical Engineering Section, Universiti Kuala Lumpur, International College

Selangor, Malaysia

${ }^{b}$ Bilal M. Eid and Nasrudin A. Rahim

UM Power Energy Dedicated Advanced Centre (UMPEDAC), Wisma R \& D, University of Malaya

Kuala Lumpur, Malaysia keeping carbon emission levels low [3]. One of the attractive DERs is the PV sources as they have advantages include; everywhere availability, zero carbon dioxide emission, and low running and maintenance cost [4].

Moreover renewable energy sources (RESs) give each nation energy dependency by reducing the energy and fuel required to be imported. These features encourage many governments to put an ambitious goal to supply a significate portion of their electrical grid from renewable energy sources such as PV (80\% in Germany by 2050 [5]). Figure 1 shows that the trend of the advanced countries in energy sector is to increase the installation of the PV capacity. Therefore they introduced variant rules and regulations to supply electrical grid from RESs such as: Feed in tariff, subsidies and income tax free [5].

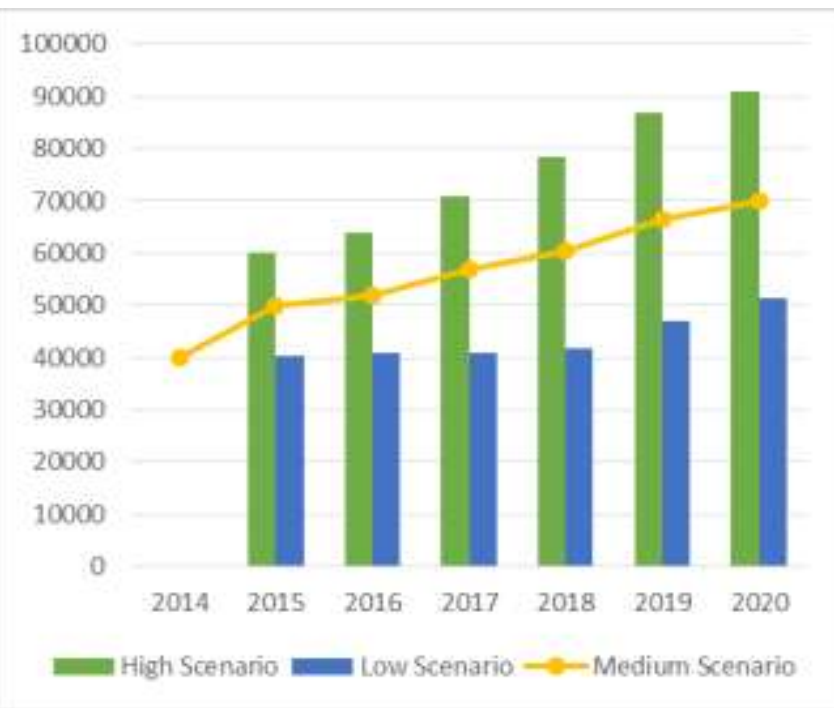

Figure 1. The annual and cumulative installed PV capacity for the year 2015 of the first nine countries (China, Japan, USA, UK, India, Germany, Korea, Australia, and France)

Malaysia introduced FiT in 2011 [6], the government encourage renewable energy (RE) projects in order to supplement fossil fuel electricity generation. Although Malaysia's RE targets are only $10 \%$ of total generation capacity by 2020 , it is clear that Malaysia has a long way to go, given that current RE capacity is around 234 MW (2014) vs. the 2,080 MW target by 2020 [6]. This indicates that there is significant room for RE expansion. The RESs included in Malaysia are Biomass, Biogas, Hydro, geothermal and PV. The FiT duration for PV was supported for a period of 21 years [7]. The FiT scheme is funded by a $1.6 \%$ levy on the electricity bill, which translates into approximately RM650m /year, based on our estimates. This would support approximately $900-1,000 \mathrm{MW}$ of total RE capacity for the next 21years [8]. 
Proc. of Sixth International Conference On Advances in Computing, Electronics and Electrical Technology - CEET 2016 Copyright $(\subseteq$ Institute of Research Engineers and Doctors. All rights reserved. ISBN no. 978-1-63248-109-2 doi: 10.15224/ 978-1-63248-109-2-21

In Turkey FiT introduced in 2010 [9] with the goal of covering $30 \%$ of the electrical grid from REs by 2023 [10]. The RESs included in FiT in Turkey are: PV, wind and hydropower, biomass and geothermal [10]. The FiT supported period for PV sources is 10 years. The period of time for the support mechanism was extended from December 31, 2015 to December 31, 2020 as the Electricity Market Regulatory Authority (EPDK) aiming to install more RE projects [10]. .

Many studies investigated financial benefit analysis for PV integration under feed-in tariff in Malaysia and Turkey $[9,11-15]$, however no one of them investigated the benefit of combination of PV sources with any other suitable business. Technical and financial perspectives are investigated in this paper, revealing the technical possibility and ROI superiority. Below sections are organized as follows; Section II presents the Feed- in tariff mechanism, basic rate and bonus, which has been followed by the PV system cost analysis in section III. In section IV, the other proposed businesses of the PV are discussed. Finally, a conclusion and future expectations has been drawn by focusing the important aspects of this paper.

\section{Feed- in tariff mechanism, basic rate and bonus}

Feed-in Tariff (FiT) is one of the most popular mechanisms applied to encourage the increase of the growth of renewable energy sources. The FiT mechanism allows electricity produced from an indigenous renewable energy source to be sold to authorized power utility companies at fixed premium price for a specific duration [7]. The basic rate paid in Malaysia is RM $1.2 / \mathrm{kWh}(0.32 \$)$ as shown in Figure 2, with additional bonus will be given to the system use locally manufactured PV and installed in the building, which can increase the FiT to $1.71 / \mathrm{kWh}(0.46 \$)$ [12]. FiT mechanism in Turkey pays $0.133 \$ / \mathrm{kWh}$ produced by $\mathrm{PV}$ units. A bonus will be given to the system use locally produced equipment this can increase the rate up to $0.2 \$$. The local equipment bonus in Turkey is available to the investor for the first 5 years [10].

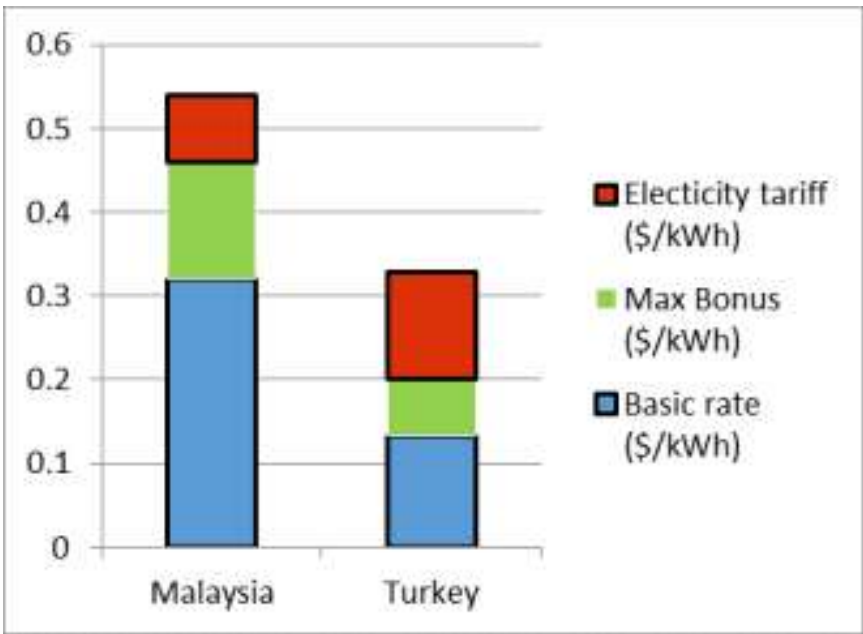

Figure 2. Basic rate paid for FiT (blue), max bonus and electricity tariff in Malaysia and Turkey

\section{PV system cost}

\section{A. Solar radiation and tilt angle:}

Malaysia lies entirely on the equatorial region with an average daily sun radiation of $4.5 \mathrm{kWh} / \mathrm{m} 2$ (6 hours of sunlight per day). The average temperature per day is $33^{\circ} \mathrm{C}$ during the day. A true South direction for PV array with tilt angle in between $2^{\circ}$ to $7^{\circ}$ gives an optimum orientation [16]. The annual average solar radiation is $1,643 \mathrm{kWh} / \mathrm{m} 2 /$ year, with maximum of $1900 \mathrm{kWh} / \mathrm{m} 2 /$ year in some locations [12] [16]. On the other hand, Turkey has total sunshine hours of $2573 \mathrm{~h}$ (the daily average is $7 \mathrm{~h}$ ). The tilt angle of the PV system is $35^{\circ}$ from the horizontal, facing due south. the average total solar radiation is $1474 \mathrm{~kW} \mathrm{h/m2/year} \mathrm{(daily} 4$ $\mathrm{kW} \mathrm{h} / \mathrm{m} 2$ ) with maximum of $1900 \mathrm{kWh} / \mathrm{m} 2 /$ year in many locations $[9,11]$.

\section{B. Net present value, Internal rate of return and payback period}

The net present value (NPV) is the sum of the present values (PVs) of incoming and outgoing cash flows over a period of time as shown in equation (1).

$$
N P V=-S+\sum_{i=1}^{y} \frac{C F_{i}}{(1+r)^{i}}
$$

Where $S$ is the initial investment in the project, $y$ is the period of project in years, $r$ is the discount rate, $C F_{i}$ is the cash flow for specific year.

Internal rate of return (IRR) is the discount rate that makes the net present value of all cash flows from a particular project equals to zero as shown in (2). This method is often used in capital budgeting to rank several projects the one with higher IRR is probably be considered the best and undertaken first.

$$
z \text { ero }=-S+\sum_{i=1}^{y} \frac{C F_{i}}{(1+I R R)^{i}}
$$

So if the NPV of the project is positive (greater than zero) and IRR is greater than the minimum acceptable rate of return (MARR), the investment considers profitable. The payback period is the number of years required to gain from the project same amount of money that have been initially invested. Payback period for PV system can be calculated via equation (3) [17].

payback period $=$

$\frac{\text { Capital } \cos t \$ / m^{2}}{\eta * \text { annual radiation }\left(\frac{K W h}{\text { year. } m^{2}}\right) * F i T(\$ / K W h)}$

Where $\eta$ is the PV panel efficiency. 
Proc. of Sixth International Conference On Advances in Computing, Electronics and Electrical Technology - CEET 2016 Copyright (C) Institute of Research Engineers and Doctors. All rights reserved. ISBN no. 978-1-63248-109-2 doi: 10.15224/ 978-1-63248-109-2-21

The profitability of the PV system can be affected by solar irradiance, discount rate, investment cost and inverter failure sensitivity analysis and probabilistic analysis have been used in [12] to study uncertainty effect. Sensitivity analysis depicts that the profitability of the PV system is mainly affected by radiation followed by FiT rate, investment cost and discount rate. The probabilistic analysis depicts that considering the current FiT and without inverter failure, the confidence level of getting the IRR higher than MARR of $12 \%$ is $75 \%$., while for the inverter failure case, the level of confidence drops to $25 \%$. The estimated NPV and IRR of the PV system for the base case equal to RM 24,826 and $13.7 \%$ respectively [12]. In [15] a $4 \mathrm{kWp}$ solar PV system has been studied the total profit (for 21 years) is calculated to be RM 102,646.02, the NPV is RM8,287.30 and the IRR is $11.97 \%$. The payback period equals 6.96 years. In [18] a $50 \mathrm{kWp}$ PV system is studied, the NPV for electricity supply over 25 years is RM558821. The operating cost per year and cost of energy per $\mathrm{kWh}$ equals to RM22645 and RM0.22 respectively. The payback period for this system is 5.5 years. In [13] a $2.5 \mathrm{kWp}$ PV system has been studied, the financial analysis shows $10.51 \%$ return on investment with a payback duration of 6.55 years, and the project can generate a total profit of more than RM $100,000.00$ throughout the contract period (21 years).

In Turkey many parameters are similar as in Malaysia, such as annual solar radiation, PV system cost, panels' efficiency and the discount rate, however NPV has lower value as the years of contract is only 10 years compared to 21 years in Malaysia, in addition the FiT rate with bonus is the double in Malaysia with $0.46 \$$ compare to $0.2 \$$ in Turkey, also the bonus valid for all the period in Malaysia where it is for only 5 years in Turkey. The only advantage in Turkey that the electricity tariff is higher as it is $12.57 \$ / \mathrm{kWh}$ compare to $7.9 \$ / \mathrm{kWh}$ in Malaysia, this make the PV electrical energy produced in Turkey more worthy [19] [20]. In addition the license in Turkey is not required for all the systems producing up to $1 \mathrm{MW},[10]$, while in Malaysia the approval from Sustainable Energy Development Authority (SEDA) is required for all capacities.

The aforementioned financial analysis is without considering three important factors; price drop from RM 16.54 (4.4\$/ installed $\mathrm{W}$ in 2012 ) to $2.91 \$$ /installed $\mathrm{W}$ (in 2015, for residential less than $50 \mathrm{~kW}$ ), the PV efficiency increased to $19.8 \%$ (from $15.3 \%$ for the same product), the radiation can be considered $1800 \mathrm{kWh} / \mathrm{m} 2 /$ year instead of 1585 (by locating the system in high radiation regions) [21].
After taking all of these factors into account the NPV increases by $20 \%$ and IRR by $10 \%$, which improving the system feasibility.

\section{Other proposed businesses}

This paper proposes that the PV panel to be installed at the top of malls or business centers roof is merged with other suitable businesses as shown in Figure 3. The PV panels will be laid on the floor of the roof. Then a floor from tempered glass will be built above the PV panel, which will be strong enough to carry people walking on it. Therefore the PV system can generate electricity at the morning, while the same space will be used for another business at the evening. This is going to increase the business ROI. The two proposed businesses are a roller skating rink or cafe.

\section{A. Roller skating rink}

Now we have glass room (floor and wall from glass) on the roof of building, this will be an interested place to be visited by people to do interesting activities such as skating. Roller skating is proposed as it has low fraction, so this will keep the glass transparency high to receive sunlight without a lot of scratches. Such kind of game in the roof of building will be so attracting and can make a $20 \%$ return on investment.

\section{B. Space requirements}

The same glass room can be used as a cafe on the roof of building. Such cafe will be so attracting for people to visit and see the nice view at the evening, moreover they will be glade to support the green energy buy visiting this nice cafe.

\section{v. Conclusions and future expectations}

This paper has presented a FiT mechanism, basic rate and bonus with improving return on investment for two developing countries (Malaysia and Turkey). The governments of both countries have incentive scheme to encourage more integration for PV projects. Positive NPV is

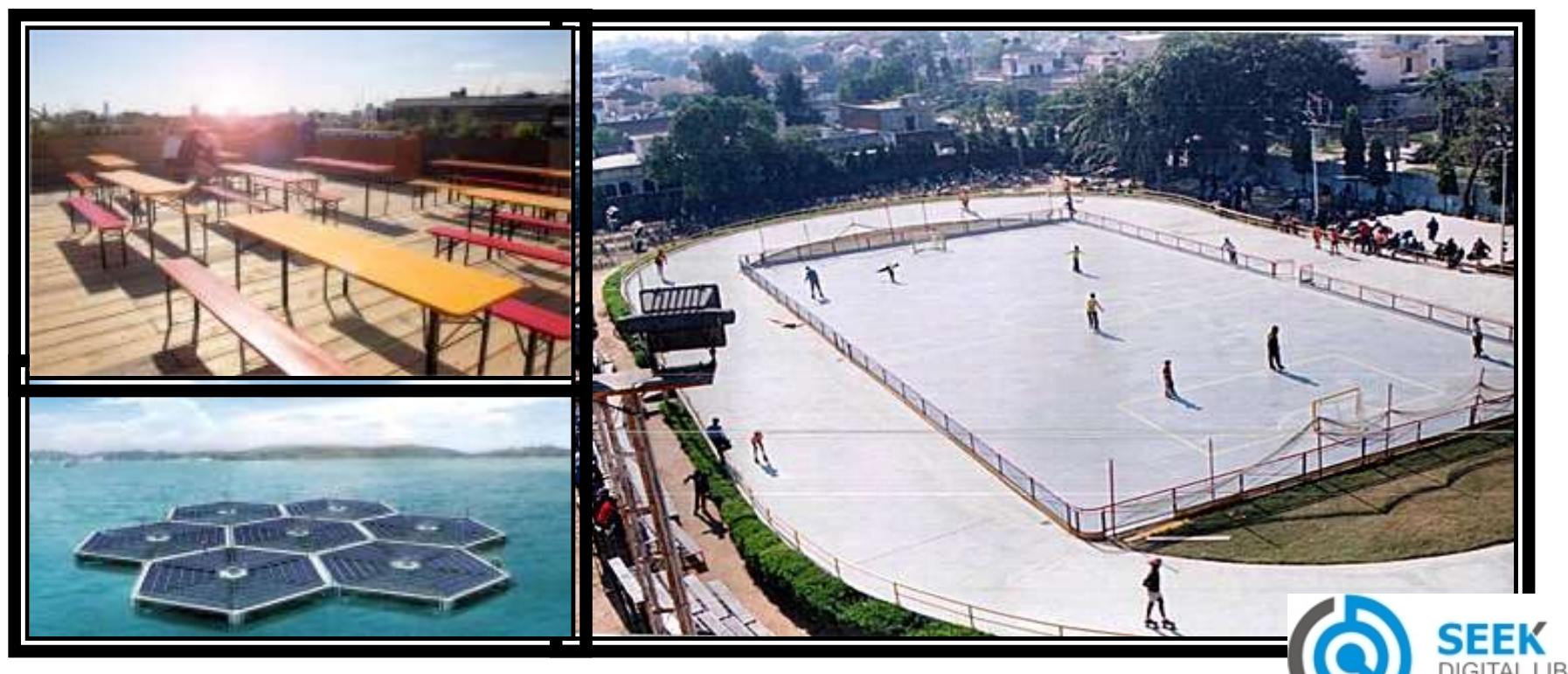


essential factor to encourage companies and individuals investing in the solar energy. Integrating PV systems with other business will increase the NPV for the projects. In addition, such projects will contribute effectively toward reducing the global warming and increase the green energy production.

This study has been investigated the PV solar system financial analysis in Malaysia and Turkey. The FiT rate in Malaysia is significantly higher and the purchase agreement is longer than in Turkey. The analysis revealed that Malaysia's potential for renewable energy generation is substantial. Its equatorial location is superb for solar system. Moreover this paper proposes the PV system to be installed at the roof of building, merged with another suitable business such as; roller skating rink or cafe. This combination make the project generating income at day time via solar radiation, while generating income at evening and night time via the other business.

The combination of PV system with roller skating rink or cafe should be considered for future work. This combination can lead to the payback period reduction and make a wonderful combination between green energy and people. In addition, the type of glass the suits more the proposed business should be investigated.

\section{Acknowledgment}

The authors thank the technical and financial assistance of Universiti Kuala Lumpur, International College and UM Power Energy Dedicated Advanced Centre (UMPEDAC).

\section{References}

[1] Writer's Handbook. Mill Valley, CA: University Science, 1989.

[2] V. Knazkins, "Stability of power systems with large amounts of distributed generation," 2004.

[3] P. Piagi and R. H. Lasseter, "Autonomous control of microgrids," in Power Engineering Society General Meeting, IEEE, 2006, p. 8

[4] M. Shamshiri, C. K. Gan, and C. W. Tan, "A review of recent development in smart grid and micro-grid laboratories," in Power Engineering and Optimization Conference (PEDCO) Melaka, Malaysia, 2012 IEEE International, 2012, pp. 367-372.

[5] O. Alsayegh, S. Alhajraf, and H. Albusairi, "Grid-connected renewable energy source systems: challenges and proposed management schemes," Energy Conversion and Management, vol. 51, pp. 1690-1693, 2010.

[6] J. von Appen, M. Braun, T. Stetz, K. Diwold, and D. Geibel, "Time in the sun: the challenge of high PV penetration in the German electric grid," Power and Energy Magazine, IEEE, vol. 11, pp. 55-64, 2013.

[7] "Eleventh Malaysia Plan," Economic Planning Unit, Putrajaya, Malaysia, 2015.

[8] "Annual Report 2013," Sustainable Energy Development Authority (SEDA), Malaysia, 2013.

[9] "Research report navigating Malaysia," CIMB Investment Bank Berhad (CIMB), Malaysia, 2015.

[10] A. Batman, F. G. Bagriyanik, Z. E. Aygen, Ö. Gül, and M. Bagriyanik, "A feasibility study of grid-connected photovoltaic systems in Istanbul, Turkey," Renewable and Sustainable Energy Reviews, vol. 16, pp. 5678-5686, 2012.

[11] "National Renewable Energy Action Plan For Turkey," Ministry Of Energy And Natural Resources, Ankara, Turkey, Dec 2014.

[12] F. Dinçer, "Overview of the photovoltaic technology status and perspective in Turkey," Renewable and Sustainable Energy Reviews, vol. 15, pp. 3768-3779, 2011.

[13] F. Albatsh, "Multirate ripple-free deadbeat control.", MS thesis, Dept. Elect. Eng., Islamic Univ. of Gaza, Gaza, Palestine, 2009.
[14] F. Muhammad-Sukki, R. Ramirez-Iniguez, S. H. Abu-Bakar, S. G. McMeekin, B. Stewart, and M. V. Chilukuri, "Feed-In Tariff for solar PV in Malaysia: Financial analysis and public perspective," in Power Engineering and Optimization Conference (PEOCO), 2011 5th International, 2011, pp. 221-226.

[15] R. Singh, G. F. Alapatt, and A. Lakhtakia, "Making solar cells a reality in every home: Opportunities and challenges for photovoltaic device design," Electron Devices Society, IEEE Journal of the, vol. 1, pp. 129-144, 2013.

[16] F. Muhammad-Sukki, A. B. Munir, R. Ramirez-Iniguez, S. H. AbuBakar, S. H. M. Yasin, S. G. McMeekin, et al., "Soft loan for domestic installation of solar photovoltaic in Malaysia: Is it the best option?," in Business Engineering and Industrial Applications Colloquium (BEIAC), 2012 IEEE, 2012, pp. 388-393.

[17] A. M. O. S. Shaari, A.H. Haris \& S.I. Sulaiman, "Solar Photovoltaic Power: Designing Grid-Connected Systems 1st ed," Ministry of Energy,Green Technology and Water, Malaysia / MBIPV . Putrajaya, Malaysia, 2010.

[18] M. Hosenuzzaman, N. Rahim, J. Selvaraj, M. Hasanuzzaman, A. Malek, and A. Nahar, "Global prospects, progress, policies, and environmental impact of solar photovoltaic power generation," Renewable and Sustainable Energy Reviews, vol. 41, pp. 284-297, 2015.

[19] A. Abdullah, M. P. Abdullah, M. Y. Hassan, and F. Hussin, "Renewable energy cost-benefit analysis under Malaysian feed-intariff," in Research and Development (SCOReD), 2012 IEEE Student Conference on, 2012, pp. 160-165.

[20] "http://www.tnb.com.my/tnb/residential/pricing-and-tariff/tariffrates.html, Tenaga Nasional Berhad, Malaysia."

[21] "http://www.tedas.gov.tr/BilgiBankasi/Sayfalar/ElektrikTarifeleri.asp x Turkish Electricity Distribution Company, Turkey."

About Author (s)

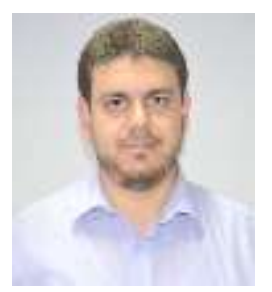

Fadi M. Albatsh received the B.S. and M.S. degrees in Electrical Engineering from the Islamic University of Gaza, Palestine, in 2006 and 2009, respectively. $\mathrm{He}$ received $\mathrm{PhD}$ degree from the University of Malaya, Kuala Lumpur, Malaysia in 2015. $\mathrm{He}$ is currently Senior Lecturer at Electrical Engineering Section, International College (ICOLE); Universiti Kuala Lumpur. His research interests include FACTS devices, power converters, power quality, power flow control, voltage stability and renewable energy.

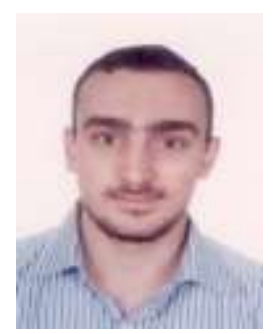

Bilal Eid received the B.Sc from the faculty of engineering, Sana'a University, Yemen, in 2008. The M. Sc. degree in electrical energy and power systems from University of Malaya, Malaysia, in 2011. The PhD in Smart grid and renewabl energy in 2016 from University of Malaya. Currently, he is a postdoctoral researcher in the Power Energy Dedicated Advanced Centre (UMPEDAC), University of Malaya. His main research interests include; Microgrid, smart grids, power conversion systems, renewable energy and photovoltaic inverters. 
Proc. of Sixth International Conference On Advances in Computing, Electronics and Electrical Technology - CEET 2016

Copyright $(\subseteq$ Institute of Research Engineers and Doctors. All rights reserved.

ISBN no. 978-1-63248-109-2 doi: 10.15224/ 978-1-63248-109-2-21

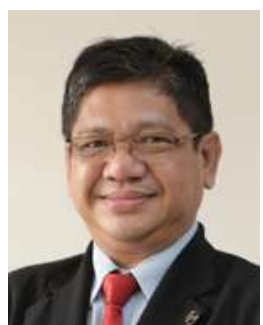

Nasrudin Abd Rahim was born in Johor, Malaysia, in 1960. He received the B.Sc. (Hons.) and M.Sc. degrees from the University of Strathclyde, Glasgow, U.K., in 1985 and 1988, respectively, and the $\mathrm{Ph} . \mathrm{D}$. degree from Heriot-Watt University, Edinburgh, U.K., in 1995.

Currently, he is a Professor with the University of Malaya, where he is the Director of power energy dedicated advanced centre (UMPEDAC) and the Chairman of the University of Malaya Advanced Engineering and Technology Research Cluster. His research interests include power electronics, real-time control systems, electrical drives, and renewable energy systems. Prof. Nasrudin is a Fellow of the Academy of Sciences Malaysia and the Institution of Engineering and Technology, U.K., and is a Chartered Engineer. 